\title{
The influence of EDTA application on the interactions of cadmium, zinc, and lead and their uptake of rainbow pink (Dianthus chinensis)
}

\author{
Hung-Yu Lai, Zueng-Sang Chen* \\ Graduate Institute of Agricultural Chemistry, National Taiwan University, No. 1, Sec. 4, Roosevelt Rd., Taipei 10617, Taiwan
}

Received 10 February 2006; received in revised form 4 May 2006; accepted 4 May 2006

Available online 11 May 2006

\begin{abstract}
Soil used in this study was artificially contaminated with $\mathrm{Cd}, \mathrm{Zn}, \mathrm{Pb}$, or applied in combinations $(\mathrm{Cd}-\mathrm{Zn}, \mathrm{Cd}-\mathrm{Pb}, \mathrm{Zn}-\mathrm{Pb}$, or $\mathrm{Cd}-\mathrm{Zn}-\mathrm{Pb})$ to study the interactions of metals in soil contaminated with multiple metals. After planting rainbow pink (Dianthus chinensis) in these soils for 21 days, three different concentrations of ethylenedinitrilotetraacetic acid (EDTA) solutions were added to study the effect of applying EDTA on the interactions among these metals. The concentrations of $\mathrm{Cd}, \mathrm{Zn}$, and $\mathrm{Pb}$ in the soil solutions of different metals-treated soils increased significantly after applying $5 \mathrm{mmolEDTA} \mathrm{kg}^{-1}$ soil $(p<0.05)$. The potential of groundwater contamination will increase after applying EDTA and it is not recommended to be in situ used or have to use very carefully. The existence of $\mathrm{Pb}$ in the $\mathrm{Cd}$-contaminated soil enhanced the uptake of $\mathrm{Cd}$ in rainbow pink in the treatments of control and 2 mmol EDTA kg-1 soil. Cadmium inhibited the concentration of Zn without applying EDTA. However, whether the application of EDTA or not and the applied EDTA concentration had the greatest effect on the uptake of Pb when compared to Cd and $\mathrm{Zn}$. After applying $5 \mathrm{mmol}$ EDTA kg ${ }^{-1}$ soil, $\mathrm{Cd}$ or $\mathrm{Zn}$ in the $\mathrm{Pb}$-contaminated soil inhibited the uptake of $\mathrm{Pb}$ in rainbow pink, but there were no effect in other treatments.
\end{abstract}

(C) 2006 Elsevier B.V. All rights reserved.

Keywords: Rainbow pink; Interaction; EDTA; $\mathrm{Cd} ; \mathrm{Zn} ; \mathrm{Pb}$

\section{Introduction}

Metals in contaminated soils can be removed by phytoextraction: plant roots uptake metals in soils and then transfer the metals into the plant shoots [1-6]. Over 420 hyperaccumulator plant species are capable of accumulating high concentrations of metals when grown in contaminated sites [7]. Many of these hyperaccumulators, however, have a low growth rates, limited biomass and require long periods of time to remove soil contaminants. Synthesized chelating agents were added to metal-contaminated soils to increase the mobility and bioavailability of metals included EDTA (ethylenedinitrilotetraacetic acid), EDDS ((S,S)- $N, N^{\prime}$-ethylenediamine disuccinic acid), DTPA (diethylenetrinitrilopentaacetic acid), HEDTA (hydroxyethylenediaminetriacetic acid), CDTA (trans1,2-cyclohexylene-dinitrilotetraacetic acid), and EGTA (ethyl-

\footnotetext{
* Corresponding author. Tel.: +88622369 8349; fax: +886223924335.

E-mail addresses: d89623401@ntu.edu.tw (H.-Y. Lai), soilchen@ntu.edu.tw (Z.-S. Chen).
}

enebis(oxyethylenetrinitrilo)tetraacetic acid), etc. [6,8-13]. However, some of these synthesized chelating agents (e.g. EDTA) have negative effects on the groundwater quality because of their persistence of biodegradation [6,10-13]. For example, EDTA will increase the solubility of metals and thus to increase their downward movement to the groundwater table. The risk of groundwater contamination was increased during EDTAassisted phytoextraction, especially for sandy soils. It should be used as a reference compound and is not recommended to be in situ used in the contaminated site. In single metal-contaminated soils, particular for $\mathrm{Pb}$-contaminated soils, applying synthetic chelating agents increased both the solubility of metal in soil and the metal concentration in plant shoots. However, the application of synthetic chelating agents reduced both plant biomass and total metal removal of metals in soils containing more than one metal because of the interactions among metals $[11,14]$. Effective application of synthetic chelating agents to soils contaminated with more than one metal represents considerable challenge for chemical enhancement of phytoextraction.

Interactions between metals in soils and those in the plants existed when soil was contaminated with metals. The Zn concen- 
tration in the young spinach leaves increased with an increasing $\mathrm{Cd}$ concentration in soil solution, but an increase of $\mathrm{Zn}$ concentration in the soil solution reduced the $\mathrm{Cd}$ concentration in the young lettuce and spinach leaves [15]. Lead competes with $\mathrm{Cd}$ for exchange sites on colloid surfaces. Consequently, the $\mathrm{Cd}$ concentration in both soil solutions and plants increased when $\mathrm{Pb}$ was existed in the soil simultaneously [16]. Carlson and Rolfe [17] identified that the Cd concentration in rye grass increased with the addition of $\mathrm{Pb}$. Other studies also reported that $\mathrm{Pb}$ had synergistic effect on Cd concentration in plants [18-20].

Using garden plants to remove metals from contaminated soils is an acceptable and satisfactory strategy as it returns contaminated sites to their natural conditions and can, if appropriate flower species are cultivated, generate economic value. Chen and Lee [21] identified that when rainbow pink was grown in a Cd-contaminated site in northern Taiwan for 5 weeks, the $\mathrm{Cd}$ concentration in plant shoots increased from $1.56 \mathrm{mg} \mathrm{kg}^{-1}$ (before planting) to $115 \mathrm{mg} \mathrm{kg}^{-1}$ (73.7-fold); the total Cd uptake was approximately $100 \mathrm{~g} \mathrm{ha}^{-1}$ year $^{-1}$. The $\mathrm{Cd}$ concentration in the shoot of plant can reach the threshold $\left(100 \mathrm{mg} \mathrm{Cd} \mathrm{kg}^{-1}\right)$ of a Cd hyperaccumulator [7]. Lai and Chen [6] reported that applying 5 or $10 \mathrm{mmolEDTA} \mathrm{kg}^{-1}$ soil significantly increased the $\mathrm{Cd}, \mathrm{Zn}$, and $\mathrm{Pb}$ concentrations in soil solution and significantly increased the $\mathrm{Pb}$ concentration in the shoot of rainbow pink when grown in a $\mathrm{Cd}-, \mathrm{Zn}-$, and $\mathrm{Pb}$-contaminated soil. However, the $\mathrm{Cd}$ and $\mathrm{Zn}$ concentration in shoots of rainbow pink did not significantly increase after applying EDTA solutions. Lai and Chen's result revealed that the effect of EDTA on phytoextraction by rainbow pink was not identical in single and combined metals-contaminated soils.

The interactions of metals in the soils contaminated with combined metals affected both the uptake of metals in plants and the effect of EDTA on the phytoextraction of combined metals in contaminated soils. The objectives of this study are: (1) to identify the interactions between $\mathrm{Cd}, \mathrm{Zn}$, and $\mathrm{Pb}$ when rainbow pink was planted to remediate soil contaminated with combined metals and (2) to evaluate the effect of EDTA on the interactions of these three metals.

\section{Materials and methods}

\subsection{Soil characteristics}

A rural soil contaminated with $\mathrm{Cd}$ and $\mathrm{Pb}$, discharged from continuous effluent cadmium ester or lead ester of industrial wastewater in 1988, was used for this experiment. The surface soil $(0-20 \mathrm{~cm})$ of the contaminated site was sampled, air-dried, and passed through a $2 \mathrm{~mm}$ (10 mesh) sieve. It was stored in large plastic containers for laboratory analysis and pot experiments. The $\mathrm{pH}$ value of the soil was measured by using glass electrodes in a soil-to-water ratio of 1:1 [22]. Soil particle size distribution was measured using a pipette method [23]. Organic carbon content was measured by the Walkley-Black wet combustion method [24]. Cation exchange capacity (CEC) was measured using the ammonium acetate method [25,26]. The total concentration of $\mathrm{Cd}, \mathrm{Zn}$, and $\mathrm{Pb}$ initially in contaminated soils were digested with aqua regia and measured with an atomic absorption spectrometer (AAS) (Hitachi 180-30 type) [27].

\subsection{The phytoextraction potentiality of rainbow pink}

To prepare the contaminated soils, a combination of three solutions, $\mathrm{Cd}\left(\mathrm{NO}_{3}\right)_{2} \cdot 4 \mathrm{H}_{2} \mathrm{O}, \mathrm{ZnO}$, or $\mathrm{Pb}\left(\mathrm{NO}_{3}\right)_{2}$, were added to the air-dried soil and in controlled concentrations (as individual element concentration) of the three metals, $20 \mathrm{mg} \mathrm{Cd} \mathrm{kg}^{-1}$, $500 \mathrm{mg} \mathrm{Zn} \mathrm{kg}^{-1}$, and $1000 \mathrm{mg} \mathrm{Pb} \mathrm{kg}^{-1}$, respectively. The soil samples contaminated with combined metals were wetted for 2 weeks by adding deionized water to maintain an average water content of $60 \%$ of the water-holding capacity (WHC) to enable the metal to reach an assumed steady state as far as possible when added to the samples. Then, the samples were dried at room temperature for approximately 4 weeks. The artificially contaminated soil was subjected to three cycles of wetting-anddrying processes, about 6 months, before the pot experiment [8]. Because of the short period of incubation of contaminated soil, probably steady state has not been reached and that the results may not be directly transferred to the field soils.

A total of $3.5 \mathrm{~kg}$ (dry weight) of artificially contaminated soil was put into plant pots $(16 \mathrm{~cm}$ in diameter and $19 \mathrm{~cm}$ in height). Two rhizon soil moisture samplers (RSMS; Eijkelkam Company, The Netherlands) were put in each pot at a depth of approximately $10 \mathrm{~cm}$ below the soil surface. Two rainbow pink (Dianthus chinensis) seedlings were planted in each pot. Pot-based experiments were conducted in a phytotron with a randomized complete block design (RCBD) with three replicates. The soil moisture content was maintained at $60 \% \mathrm{WHC}$ by weighing and adding deionized water every 2 days. The rainbow pink shoots were harvested after planting in the combined metals-contaminated soils for 50 days. The harvested plants were oven-dried at $60{ }^{\circ} \mathrm{C}$ for $72 \mathrm{~h}$, weighed, and ground into particles $0.5 \mathrm{~mm}$ in size for analysis. Then, $0.2 \mathrm{~g}$ of the plants were digested with the $\mathrm{H}_{2} \mathrm{SO}_{4} / \mathrm{H}_{2} \mathrm{O}_{2}$ method [28]. The digested solutions were filtered through Whatman No. 42 filter papers, and then diluted with deionized water to a volume of $50 \mathrm{~mL}$ in a flask. The $\mathrm{Cd}, \mathrm{Zn}$, and $\mathrm{Pb}$ concentrations were measured with an AAS (Hitachi 180-30 type).

The soils after pot experiments were sampled and the 0.05 M EDTA (pH 7.0) [29] and 0.005 M DTPA (pH 5.3) [30] extractable $\mathrm{Cd}, \mathrm{Zn}$, and $\mathrm{Pb}$ concentrations and total concentration (aqua regia method) [27] in soils were measured with an AAS (Hitachi 180-30). Soil solutions were also collected with an RSMS prior to harvesting. The bioavailable concentrations of $\mathrm{Cd}, \mathrm{Zn}$, and $\mathrm{Pb}$ in the contaminated soils were evaluated from the concentrations of metals in the soil solution, which were determined with an inductively coupled plasma optical emission spectrometer (ICP-OES) (Perkin-Elmer 2000 DV).

\subsection{Interaction study: pre-experiment and soil treatments}

The withered yellow of leaves of rainbow pink caused by soil toxicities affect the accumulated metal concentrations in rainbow pink shoots and, thus, affect the determination of the interactions between metals. To avoid this potential prob- 
Table 1

The physical and chemical characteristics of the study soil

\begin{tabular}{|c|c|c|c|c|c|c|}
\hline \multirow[t]{2}{*}{$\mathrm{pH}\left(\mathrm{H}_{2} \mathrm{O}\right)$} & \multirow[t]{2}{*}{ O.C. ${ }^{\mathrm{a}}\left(\mathrm{g} \mathrm{kg}^{-1}\right)$} & \multirow[t]{2}{*}{ Texture } & \multirow[t]{2}{*}{$\mathrm{CEC}^{\mathrm{b}}\left(\mathrm{cmol}_{(+)} \mathrm{kg}^{-1}\right.$ soil $)$} & \multicolumn{3}{|c|}{ Total concentration $\left(\mathrm{mg} \mathrm{kg}^{-1}\right)^{\mathrm{c}}$} \\
\hline & & & & $\mathrm{Cd}$ & $\mathrm{Zn}$ & $\mathrm{Pb}$ \\
\hline 4.9 & 16.9 & Silty clay ${ }^{\mathrm{d}}$ & 13.9 & $2.58 \pm 0.08$ & $80.0 \pm 5.32$ & $31.3 \pm 2.09$ \\
\hline
\end{tabular}

lem, rainbow pink was planted in the concentrations of $\mathrm{Cd}$ treated soils $\left(5,10\right.$, and $\left.15 \mathrm{mg} \mathrm{kg}^{-1}\right), \mathrm{Zn}$-treated soils $(500$, 1000 , and $1500 \mathrm{mg} \mathrm{kg}^{-1}$ ), or Pb-treated soils (500, 1000, and $1500 \mathrm{mg} \mathrm{kg}^{-1}$ ) that were first incubated with the same process described in Section 2.2, to determine the maximum allowable metal concentrations in soils. After growing rainbow pink for 1 month in the phytotron, the health of plants was recorded and utilized to determine the suitable concentration of artificially added $\mathrm{Cd}, \mathrm{Zn}$, or $\mathrm{Pb}$ for the pot-based experiment in Section 2.4 .

After determining the suitable concentrations of $\mathrm{Cd}, \mathrm{Zn}$, or $\mathrm{Pb}$ during the pre-experiment stage, single or combined solutions of $\mathrm{Cd}\left(\mathrm{NO}_{3}\right)_{2} \cdot 4 \mathrm{H}_{2} \mathrm{O}, \mathrm{ZnO}$, or $\mathrm{Pb}\left(\mathrm{NO}_{3}\right)_{2}$ were added to the airdried soil to control the three metals as following treatments: (1) CK denotes initially contaminated soil sampled from the Cd-contaminated site; (2) Cd-treated soil denotes soil contaminated with Cd; (3) Zn-treated soil denotes soil contaminated with $\mathrm{Zn}$; (4) $\mathrm{Pb}$-treated soils denotes soils contaminated with $\mathrm{Pb}$; (5) $\mathrm{Cd}-\mathrm{Zn}$-treated soil denotes soil contaminated with $\mathrm{Cd}$ and $\mathrm{Zn}$; (6) $\mathrm{Cd}-\mathrm{Pb}$-treated soil denotes soil contaminated with $\mathrm{Cd}$ and $\mathrm{Pb}$; (7) $\mathrm{Zn}-\mathrm{Pb}$-treated soil denotes soil contaminated with $\mathrm{Zn}$ and $\mathrm{Pb}$; (8) $\mathrm{Cd}-\mathrm{Zn}-\mathrm{Pb}$-treated soil denotes soil contaminated with $\mathrm{Cd}, \mathrm{Zn}$, and $\mathrm{Pb}$. The different metal-treated soils were subjected to the process of incubation as described in Section 2.2.

\subsection{Interaction study: pot experiment and laboratory analysis}

Each pot $(16 \mathrm{~cm}$ in diameter and $19 \mathrm{~cm}$ in height $)$ contained $3.0 \mathrm{~kg}$ (dry weight) of different metal-treated soils. Two RSMS were put in each pot at a depth of around $10 \mathrm{~cm}$ below the soil surface. One rainbow pink (D. chinensis) seedling was planted in each pot. The pot-based experiment was conducted in the phytotron using an RCBD with three replicates. The soil moisture content was maintained at $60 \%$ WHC by weighing and adding deionized water every 2 days.

To make sure the uniform effect of applying EDTA solutions into pot soils, final soil water content will not exceed the WHC. After rainbow pink was planted in the soil for 21 days, $300 \mathrm{~mL}$ of three $\mathrm{Na}_{2}$-EDTA solutions (pH 5.0) (0 (control), 2 , and $5 \mathrm{mmol} \mathrm{kg}^{-1}$ soil) were added to the different metal-treated soils. The plants' growth conditions and symptoms of toxicity were observed and recorded. The rainbow pink shoots were harvested on seventh day after the EDTA solution was added to the potted soil. The harvested plants were treated and the concen- trations of $\mathrm{Cd}, \mathrm{Zn}$, and $\mathrm{Pb}$ were measured with the same process as described in Section 2.2.

Soil solutions were also collected with an RSMS prior to adding EDTA solutions and on the seventh day after adding EDTA solutions. The concentrations of $\mathrm{Cd}, \mathrm{Zn}$, and $\mathrm{Pb}$ in the soil solutions were measured with an ICP-OES (Perkin-Elmer $2000 \mathrm{DV})$.

\subsection{Statistics}

The variance and significance of the differences among concentrations of elements in the soil solutions, extractants, and in the plants were analyzed by ANOVA. Statistical significance was defined as $p=0.05$.

\section{Results}

\subsection{Soil characteristics}

Table 1 lists the physical and chemical characteristics of the studied soil. The soil texture was silty clay with a moderate cation exchange capacity of $13.9 \mathrm{cmol}_{(+)} \mathrm{kg}^{-1}$ soil; its $\mathrm{pH}$ value was 4.9 and the organic carbon was $16.9 \mathrm{~g} \mathrm{~kg}^{-1}$. The initial total metal concentrations in the contaminated soil, digested with aqua regia, were $2.58 \pm 0.08 \mathrm{mg} \mathrm{Cd} \mathrm{kg}^{-1}$, $80.0 \pm 5.32 \mathrm{mg} \mathrm{Zn} \mathrm{kg}^{-1}$, and $31.3 \pm 2.09 \mathrm{mg} \mathrm{Pb} \mathrm{kg}^{-1}$.

\subsection{The phytoextraction potentiality of rainbow pink}

The $\mathrm{Cd}, \mathrm{Zn}$, and $\mathrm{Pb}$ concentrations in the soil solutions and in soil digested with aqua regia or extracted with $0.005 \mathrm{M} \mathrm{DTPA}$ (pH 5.3) or 0.05 M EDTA ( $\mathrm{pH} 7.0$ ) after planting rainbow pink for 50 days are shown in Table 2. The total concentrations of $\mathrm{Cd}$, $\mathrm{Zn}$, and $\mathrm{Pb}$ in the soils contaminated with combination of metals

Table 2

The $\mathrm{Cd}, \mathrm{Zn}$, and $\mathrm{Pb}$ concentration in soil solution and in soil digested by aqua regia or extracted by $0.005 \mathrm{M}$ DTPA or $0.05 \mathrm{M}$ EDTA after planting rainbow pink for 50 days

\begin{tabular}{lllll}
\hline \multicolumn{4}{l}{ Analytic methods } \\
\cline { 2 - 5 } & $\begin{array}{l}\text { Soil solution } \\
\left(\mathrm{mg} \mathrm{L}^{-1}\right)\end{array}$ & $\begin{array}{l}\text { Aqua regia } \\
\left(\mathrm{mg} \mathrm{kg}^{-1}\right)\end{array}$ & $\begin{array}{l}0.05 \mathrm{M} \mathrm{EDTA} \\
\left(\mathrm{mg} \mathrm{kg}^{-1}\right)\end{array}$ & $\begin{array}{l}0.005 \mathrm{M} \mathrm{DTPA} \\
\left(\mathrm{mg} \mathrm{kg}^{-1}\right)\end{array}$ \\
\hline $\mathrm{Cd}$ & $3.72 \pm 0.76$ & $17.4 \pm 0.86$ & $18.5 \pm 0.46$ & $17.1 \pm 0.62$ \\
$\mathrm{Zn}$ & $95.7 \pm 17.8$ & $458 \pm 26.3$ & $360 \pm 7.51$ & $336 \pm 7.80$ \\
$\mathrm{~Pb}$ & $4.73 \pm 1.48$ & $938 \pm 45.5$ & $822 \pm 51.9$ & $671 \pm 45.2$ \\
\hline
\end{tabular}


were $17.4 \pm 0.86,458 \pm 26.3$, and $938 \pm 45.5 \mathrm{mg} \mathrm{kg}^{-1}$, respectively. These metal concentrations are about 87,92 , and $94 \%$ of the target concentrations of $20 \mathrm{mg} \mathrm{Cd} \mathrm{kg}^{-1}, 500 \mathrm{mg} \mathrm{Zn} \mathrm{kg}^{-1}$, and $1000 \mathrm{mg} \mathrm{Pb} \mathrm{kg}^{-1}$. These metal concentrations are close to the target values of contamination if we consider the variation of concentrations distributed in the contamination site. To take the total $\mathrm{Pb}$ concentration of $1000 \mathrm{mg} \mathrm{kg}^{-1}$ for interpretation, the $\mathrm{Pb}$ concentration in the soil solution was low and revealed that $\mathrm{Pb}$ was not soluble in the soil. The $0.005 \mathrm{M}$ DTPA (pH 5.3) and 0.05 M EDTA ( $\mathrm{pH} 7.0$ ) extracted almost the same concentrations of $\mathrm{Cd}$ and $\mathrm{Zn}$ in the contaminated soils, but not so for $\mathrm{Pb}$. Both extractors, $0.005 \mathrm{M}$ DTPA and 0.05 M EDTA, extracted most of the $\mathrm{Cd}$ and about $70-80 \%$ of the $\mathrm{Zn}$ and $\mathrm{Pb}$ from the artificially contaminated soil with combined metals. Previous studies showed that $0.05 \mathrm{M}$ EDTA and $0.005 \mathrm{M}$ DTPA extracted the same fractions metals in soil including water soluble, exchangeable, and organically bounding forms [31-35]. Experimental results of both $0.05 \mathrm{M}$ EDTA and 0.005 M DTPA extractable metals concentrations showed that the metals added to the soil were easy to uptake by plants [20].

After growing rainbow pink in the soils contaminated with multiple metals for 50 days, the $\mathrm{Cd}, \mathrm{Zn}$, and $\mathrm{Pb}$ concentrations in the shoots of rainbow pink were $82.2 \pm 11.0,3736 \pm 577$, and $216 \pm 166 \mathrm{mg} \mathrm{kg}^{-1}$, respectively. Except for the low Pb concentration in the soil solution, rainbow pink accumulated high concentrations of $\mathrm{Cd}$ and $\mathrm{Zn}$ in their shoots. Experimental result was similar to that reported by Chen and Lee [21]. The accumulated $\mathrm{Cd}$ concentration was also close the threshold value of a Cd hyperaccumulator $\left(100 \mathrm{mg} \mathrm{kg}^{-1}\right)$ [7]. These results revealed that rainbow pink was potentially effective for phytoremediation of soils contaminated with multiple metals and uptake measurements demonstrated high concentration of $\mathrm{Cd}$ and $\mathrm{Zn}$ in plant shoots.

\subsection{Pre-experiment results}

Among the three Cd-treated soils (5, 10, and $15 \mathrm{mg} \mathrm{Cd} \mathrm{kg}^{-1}$ ) and the three $\mathrm{Pb}$-treated soils $\left(500,1000\right.$, and $1500 \mathrm{mg} \mathrm{Pb} \mathrm{kg}^{-1}$ ), rainbow pink grew well when planted in the 5 or $10 \mathrm{mg} \mathrm{Cd} \mathrm{kg}^{-1}$. and 500 or $1000 \mathrm{mg} \mathrm{Pb} \mathrm{kg}^{-1}$-treated soils. However, chlorosis occurred in the tips of leaves when planted in the $15 \mathrm{mg} \mathrm{Cd} \mathrm{kg}^{-1}$. or $1500 \mathrm{mg} \mathrm{Pb} \mathrm{kg}^{-1}$-treated soil. Among the three different $\mathrm{Zn}$ concentrations (500, 1000, and $1500 \mathrm{mg} \mathrm{Zn} \mathrm{kg}^{-1}$ ) applied in the pre-experiment, most leaves were damaged by the toxicity of $\mathrm{Zn}$ in soil and showed withering and yellowing. For considering the healthy plants to explain the interactions of metals, the $\mathrm{Cd}, \mathrm{Zn}$, and $\mathrm{Pb}$ concentrations in the artificially addition to the initial contaminated soil were determined as 10,100 , and $1000 \mathrm{mg} \mathrm{kg}^{-1}$, respectively.

\subsection{The concentration changes of elements in soil solutions after applying EDTA}

Artificially added $\mathrm{Cd}, \mathrm{Zn}$, or $\mathrm{Pb}$ to the initial metalscontaminated soil increased the concentrations of specific metals in the soil solution (Fig. 1). For instance, adding

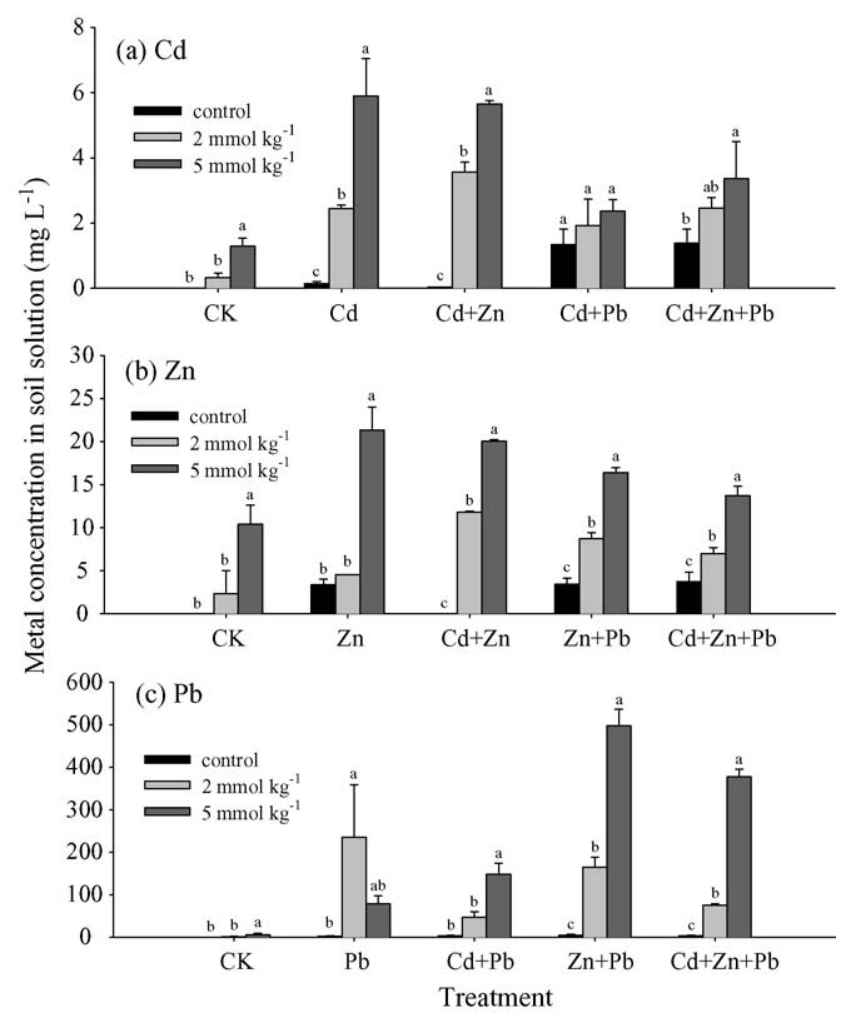

Fig. 1. The effect of applying different concentrations of EDTA on: (a) Cd concentration, (b) $\mathrm{Zn}$ concentration, and (c) $\mathrm{Pb}$ concentration in soil solution. The probability level of significant difference is at $p=0.05$. Replicates $(n)=3$.

$\mathrm{Cd}\left(\mathrm{NO}_{3}\right)_{2}$ to the soil raised the level $\mathrm{Cd}$ concentration in the soil solution from not detectable (ND, below the detection limit of $0.0027 \mathrm{mg} \mathrm{L}^{-1}$ ) in initially contaminated soil (CK) to $0.14 \pm 0.07 \mathrm{mg} \mathrm{L}^{-1}$ (Cd-treated soil), $0.03 \pm 0.01 \mathrm{mg} \mathrm{L}^{-1}$ (Cd-Zn-treated soil), $1.34 \pm 0.47 \mathrm{mg} \mathrm{L}^{-1}$ (Cd-Pb-treated soil), and $1.38 \pm 0.43 \mathrm{mg} \mathrm{L}^{-1}(\mathrm{Cd}-\mathrm{Zn}-\mathrm{Pb}$-treated soil), respectively (Fig. 1a). Possessing the same result with that treated with $\mathrm{Cd}$ solution, artificial adding $\mathrm{ZnO}$ or $\mathrm{Pb}\left(\mathrm{NO}_{3}\right)_{2}$ also increased the $\mathrm{Zn}$ or $\mathrm{Pb}$ concentrations in the soil solutions (Fig. $1 \mathrm{~b}$ and $\mathrm{c}$ ).

In most of the single or combined metals-treated soils, applying 5 mmol EDTA $\mathrm{g}^{-1}$ soil significantly increased the concentrations of $\mathrm{Cd}, \mathrm{Zn}$, or $\mathrm{Pb}$ in soil solutions $(p<0.05)$ (Fig. 1). This result was similar to that in other studies $[6,8-11,13,14,36]$. EDTA can complex with soil metals, which are in the low available fractions initially, and thus to increase the metal concentrations in the soil solutions. Experimental result also revealed that the potential risk of groundwater contamination will increase after applying EDTA and it should be used very carefully or use biodegradable substitutes, like EDDS [12]. Soil used in this study was contaminated with $\mathrm{Cd}$ as a result of wastewater discharged by industrial plants. The total concentrations of $\mathrm{Cd}, \mathrm{Zn}$, and $\mathrm{Pb}$ in the initially contaminated soil measured with aqua regia were $2.58 \pm 0.08,80.0 \pm 5.32$, and $31.3 \pm 2.09 \mathrm{~m} \mathrm{~kg}^{-1}$, respectively. In CK, without artificially added metals, applying 5 mmol EDTA kg ${ }^{-1}$ soil solutions significantly increased the concentrations of $\mathrm{Cd}, \mathrm{Zn}$, or $\mathrm{Pb}$ in soil solutions $(p<0.05)$. However, the increase was minimal compared to other treatments because of the low concentrations of $\mathrm{Cd}, \mathrm{Zn}$, and $\mathrm{Pb}$ initial in 
the soil. The $\mathrm{Cd}, \mathrm{Zn}$, and $\mathrm{Pb}$ concentrations in soil solution after applying 2 mmol EDTA kg-1 soil also increased, however, some were not statistically significantly.

Experimental results of this study revealed that applying 2 or 5 mmol EDTA $\mathrm{kg}^{-1}$ soil significantly increased most of the $\mathrm{Cd}$, $\mathrm{Zn}$, and $\mathrm{Pb}$ concentrations in soil solutions of different metaltreated soils $(p<0.05)$. However, because of the soils low permeability (silty clay) compared to soils employed in other studies $[9,14,37,38]$ and also because of the low EDTA application rate ( 2 mmol EDTA kg ${ }^{-1}$ soil) used in this study, the effect of EDTA was only statistically significant for $5 \mathrm{mmolEDTA} \mathrm{kg}^{-1}$ soil $(p<0.05)$.

\subsection{The interactions of $\mathrm{Cd}, \mathrm{Zn}$, and $\mathrm{Pb}$}

The interactions between the metals in contaminated soil and accumulated in the rainbow pink shoots were identified by utilizing the concentration of metal in the rainbow pink shoots. Enhancement (EH), inhibition (IH), or no effect (NE) was determined by the guidance as shown in Table 3 . When soil has $\mathrm{X}$ and $\mathrm{Y}$ elements at the same time, the concentration of $\mathrm{Y}$ in the growing plant significantly increased $(p<0.05)$ compared with that growing in the soil only has high concentration of Y element. Then, we say the $\mathrm{X}$ element has enhancement effect on the uptake of Y element.

In the control, without applying EDTA solutions, the $\mathrm{Cd}$ concentration in rainbow pink shoots increased significantly in the $\mathrm{Cd}-\mathrm{Zn}$-treated soil compared with the Cd-treated soil $(p<0.05)$ (Fig. 2). Without applying EDTA, the addition of $\mathrm{Zn}$ to the soil significantly increased the $\mathrm{Cd}$ concentration in the plant shoots from ND $(<0.68)$ to $14.0 \pm 0.00 \mathrm{mg} \mathrm{kg}^{-1}$ $(p<0.05)$. The addition of $\mathrm{Zn}$ in the Cd-contaminated soil enhanced the $\mathrm{Cd}$ concentrations in rainbow pink shoots. Result of previous studies showed that $\mathrm{Zn}$ could reduce the uptake of $\mathrm{Cd}$ by both root and foliar parts. Experimental result of this study was similar to two reports [20,39]. However, the $\mathrm{Cd}$ concentrations in the rainbow pink shoots when growing in the $\mathrm{Cd}-\mathrm{Zn}$-treated soil significantly decreased $(p<0.05)$ in the treatment of 2 mmolEDTA kg-1 soil or decreased in the treatment of 5 mmolEDTA kg${ }^{-1}$ soil compared to growing in the Cd-treated soil. The artificially contaminated soil has higher molecular number of $\mathrm{Zn}\left(1.53 \mathrm{mmol} \mathrm{kg}^{-1}\right)$ in relative to $\mathrm{Cd}$ $\left(0.089 \mathrm{mmol} \mathrm{kg}^{-1}\right)$. After applying 2 or 5 mmolEDTA kg-1 soil, the soil solution of $\mathrm{Cd}-\mathrm{Zn}$-treated soil also has higher $\mathrm{Zn}$ concentration compared to control treatment without applying EDTA (Fig. 1b). Besides, $\mathrm{Zn}$ is an essential element for the

Table 3

The guidance used in this study to determine the interactions of metals

\begin{tabular}{llll}
\hline Interaction & Code & Metal concentration changed & Significantly different \\
\hline Enhancement & $\mathrm{EH}$ & Trend to increase & $p<0.05$ \\
Inhibition & $\mathrm{IH}$ & Trend to decrease & $p<0.05$ \\
No effect & $\mathrm{NE}$ & Trend to increase & $\mathrm{NS}^{\mathrm{a}}$ \\
No effect & $\mathrm{NE}$ & Trend to decrease & $\mathrm{NS}$ \\
No effect & $\mathrm{NE}$ & Have no trend & $\mathrm{NS}$ \\
\hline
\end{tabular}

${ }^{a}$ No significant difference.

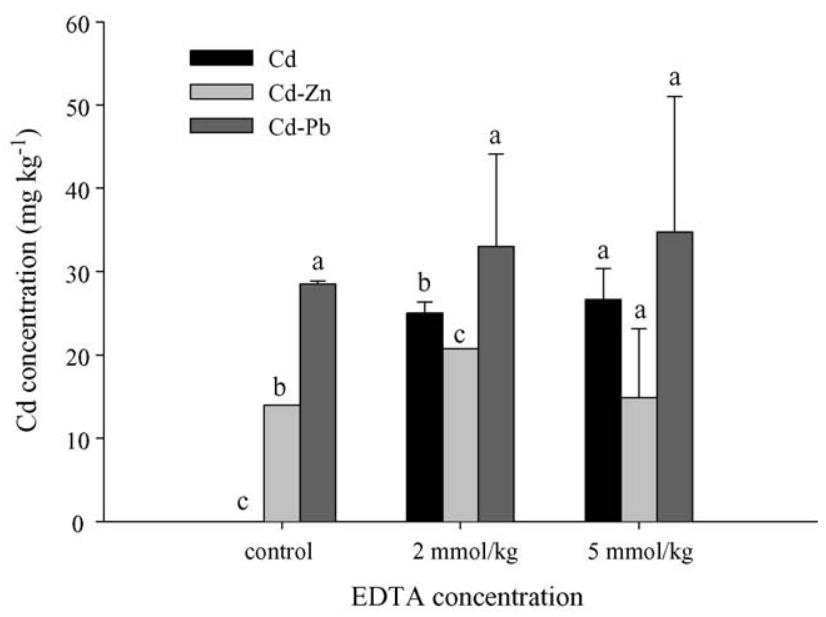

Fig. 2. The concentrations of $\mathrm{Cd}$ in the shoots of rainbow pink after planting in the different metals-treated soils, which was harvested at 7th day after applying different concentrations of EDTA. The probability level of significant difference is at $p=0.05$. Replicates $(n)=3$.

growth of plants. Rainbow pink thus accumulated significantly higher $\mathrm{Zn}$ concentration in their shoots and thus decreased the $\mathrm{Cd}$ uptake when it grown in the $\mathrm{Cd}-\mathrm{Zn}$-treated soil $(p<0.05)$ (Fig. 2) compared to Cd-treated soil. The EH effect of the $\mathrm{Cd}$ uptake in rainbow pink by adding $\mathrm{Zn}$ to soil without adding EDTA disappeared and became to IH or NE after applying 2 or 5 mmol EDTA kg-1 soil, respectively. The addition of $\mathrm{Pb}$ $(\mathrm{Cd}-\mathrm{Pb}$-treated soil) significantly increased the $\mathrm{Cd}$ concentration in the rainbow pink shoots from ND to $28.5 \pm 0.35 \mathrm{mg} \mathrm{kg}^{-1}$ $(p<0.05)$ without applying EDTA (Fig. 2). Lead was demonstrated to compete against $\mathrm{Cd}$ on the adsorbing sites of soil particles. The $\mathrm{Cd}$ concentration in soil solution (Fig. 1a) and in the shoots of rainbow pink (Fig. 2) was thus significantly increased in $\mathrm{Cd}-\mathrm{Pb}$-treated soil compared to Cd-treated soil $(p<0.05)$ without applying EDTA. Study results demonstrated that the existence of $\mathrm{Pb}$ in $\mathrm{Cd}$-contaminated soil had an $\mathrm{EH}$ effect on the $\mathrm{Cd}$ concentration in rainbow pink shoots without applying EDTA. Previous studies reported that the addition of $\mathrm{Zn}$ or $\mathrm{Pb}$ had synergistic effects on the $\mathrm{Cd}$ accumulated in plants $[16,17,20,39]$. The observation results of this study were similar to previous studies. When comparing the result in $\mathrm{Cd}-\mathrm{Pb}$-treated soil with that result for Cd-treated soils after application of two EDTA concentrations, the $\mathrm{Cd}$ concentration in the plant shoots increased when grown in the $\mathrm{Cd}-\mathrm{Pb}$-treated soil; however, the increases were only statistically significant in the treatment of 2 mmol EDTA kg${ }^{-1}$ soil $(p<0.05)$. Regardless of whether EDTA applied, the existence of $\mathrm{Pb}$ in the $\mathrm{Cd}$-contaminated soils increased the $\mathrm{Cd}$ concentration in rainbow pink shoots. Lead had an $\mathrm{EH}$ effect on the $\mathrm{Cd}$ concentration in the rainbow pink shoots for most treatments. In the treatment of $5 \mathrm{mmol} \mathrm{EDTA} \mathrm{kg}^{-1}$ soil, the addition of $\mathrm{Pb}$ also increased the $\mathrm{Cd}$ concentration in the shoots, but was not statistically significantly because the variation was larger than those for the other treatments.

The existence of $\mathrm{Cd}$ in the $\mathrm{Zn}$-contaminated soil decreased the $\mathrm{Zn}$ concentration in the rainbow pink shoots with or without applying EDTA, but was only statistically significant without applying EDTA $(p<0.05)$ (Fig. 3). In the con- 


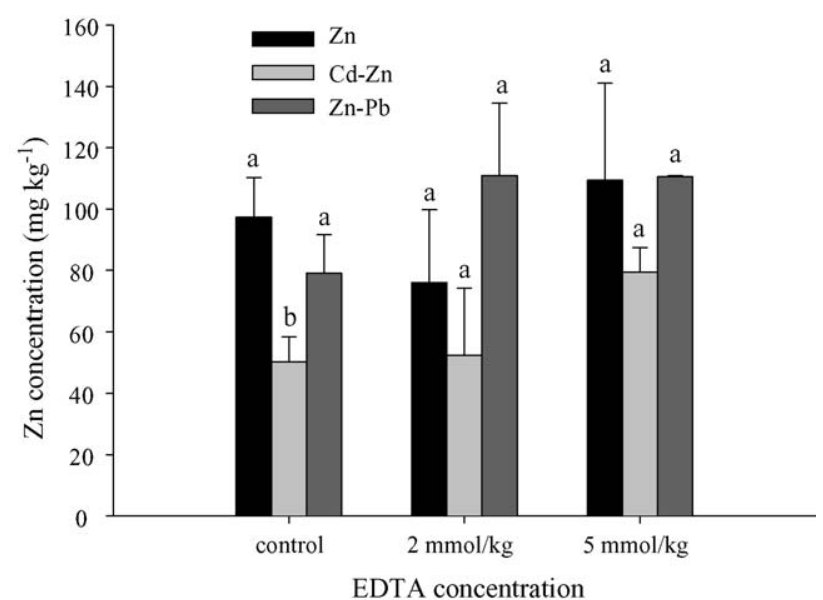

Fig. 3. The concentrations of $\mathrm{Zn}$ in the shoots of rainbow pink after planting in the different metals-treated soils, which was harvested at 7th day after applying different concentrations of EDTA. The probability level of significant difference is at $p=0.05$. Replicates $(n)=3$.

trol with applying EDTA, the $\mathrm{Zn}$ concentration in the shoots decreased significantly from $97.3 \pm 13.0 \mathrm{mg} \mathrm{kg}^{-1}$ (Zn-treated soil) to $50.3 \pm 8.13 \mathrm{mg} \mathrm{kg}^{-1}$ (Cd-Zn-treated soil) $(p<0.05)$. Cadmium had an IH effect on the $\mathrm{Zn}$ concentration in the shoot of rainbow pink without applying EDTA. Without applying EDTA, Zn-treated soil has higher Zn concentration in soil solution compared to Cd-Zn-treated soil (Fig. 1b). Rainbow pink thus accumulated significantly higher $\mathrm{Zn}$ concentration in their shoots when grown in the $\mathrm{Cd}-\mathrm{Zn}$-treated soil compared to that in the Zn-treated soil (Fig. 3). This experimental result agreed with results in previous studies [20,39]. After applying 2 and 5 mmol EDTA $\mathrm{g}^{-1}$ soil, the $\mathrm{Zn}$ concentration in the shoots decreased from $76.0 \pm 23.7 \mathrm{mg} \mathrm{kg}^{-1}$ (Zn-treated soil) to $52.4 \pm 21.7 \mathrm{mg} \mathrm{kg}^{-1}$ (Cd-Zn-treated soil) and from $109 \pm 31.6 \mathrm{mg} \mathrm{kg}^{-1}$ (Zn-treated soil) to $79.4 \pm 7.95 \mathrm{mg} \mathrm{kg}^{-1}$ (Cd-Zn-treated soil). The application of both EDTA concentrations changed the IH effect of $\mathrm{Cd}$ without applying EDTA, to that of NE after applying EDTA. Lead had NE on the Zn concentration in the shoots (Fig. 3). In the control without applying EDTA, the $\mathrm{Zn}$ concentration in the shoots decreased from $97.3 \pm 13.0 \mathrm{mg} \mathrm{kg}^{-1}$ (Zn-treated soil) to $79.0 \pm 12.6 \mathrm{mg} \mathrm{kg}^{-1}$ (Zn-Pb-treated soil). After applying 2 mmol EDTA kg ${ }^{-1}$ soil, the existence of $\mathrm{Pb}$ increased the $\mathrm{Zn}$ concentration in the shoots from $76 \pm 23.7 \mathrm{mg} \mathrm{kg}^{-1}$ (Zn-treated soil) to $111 \pm 23.6 \mathrm{mg} \mathrm{kg}^{-1}$ ( $\mathrm{Zn}-\mathrm{Pb}$-treated soil), however, this increase was not statistically significant. After applying $5 \mathrm{mmolEDTA} \mathrm{kg}{ }^{-1}$ soil, the $\mathrm{Zn}$ concentrations in the shoots grown in both $\mathrm{Zn}$ - and $\mathrm{Zn}-\mathrm{Pb}$ treated soils were about $110 \mathrm{mg} \mathrm{kg}^{-1}$. The addition of $\mathrm{Pb}$ to soil had NE on the Zn concentration in the shoots after applying 5 mmolEDTA kg-1 soil. The added $\mathrm{Pb}$ in soil had NE on the $\mathrm{Zn}$ concentration in the shoots with or without applying EDTA. The antagonism of $\mathrm{Zn}$ on the uptake of $\mathrm{Pb}$ by plants was reported by previous study [20]. However, no interaction was found between $\mathrm{Zn}$ and $\mathrm{Pb}$ with or without applying EDTA although $\mathrm{Zn}$ concentrations were significantly increased after applying 2 or 5 mmol EDTA kg ${ }^{-1}$ soil $(p<0.05)$. We supposed that the preferred uptake of rainbow pink on $\mathrm{Zn}$ was the possi-

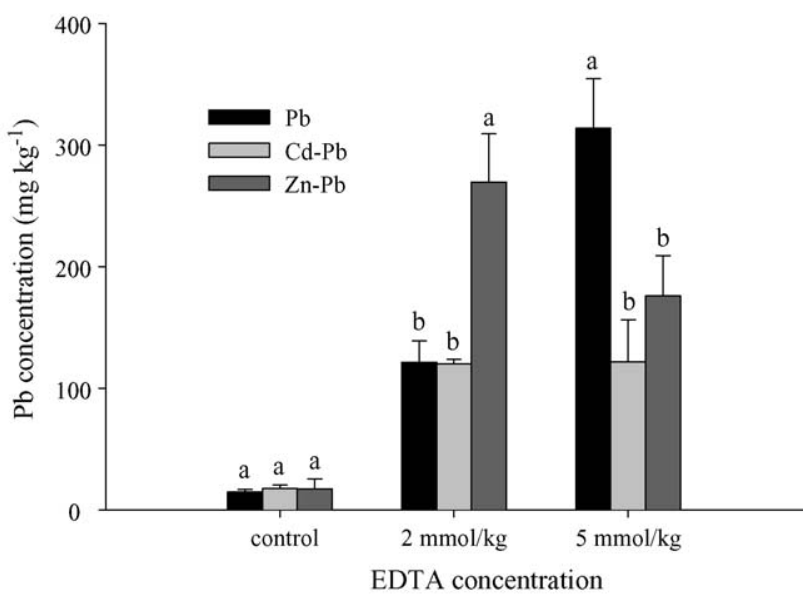

Fig. 4. The concentrations of $\mathrm{Pb}$ in the shoots of rainbow pink after planting in the different metals-treated soils, which was harvested at 7 th day after applying different concentrations of EDTA. The probability level of significant difference is at $p=0.05$. Replicates $(n)=3$.

ble reason because $\mathrm{Zn}$ is an essential element for the growth of plants under this concentration of $\mathrm{Zn}$.

The $\mathrm{Pb}$ concentration in the shoots of rainbow pink planted in the $\mathrm{Pb}-, \mathrm{Cd}-\mathrm{Pb}$ - or $\mathrm{Zn}-\mathrm{Pb}$-treated soils without applying EDTA were all about $15 \mathrm{mg} \mathrm{kg}^{-1}$, which was only $1.5 \%$ of the total $\mathrm{Pb}$ concentration in soil. The addition of $\mathrm{Cd}$ or $\mathrm{Zn}$ had $\mathrm{NE}$ on the $\mathrm{Pb}$ concentration in the shoots without applying EDTA solutions (Fig. 4). The low Pb concentration in the shoots of rainbow pink was resulted from the low $\mathrm{Pb}$ concentration in soil solution (Fig. 1c). Analyzed result showed that most of the spiked $\mathrm{Pb}$ in the study soil was in the nonavailable fractions for the uptake of rainbow pink. Similar to the results for the control without applying EDTA, the added $\mathrm{Cd}$ in $\mathrm{Pb}$-treated soils had $\mathrm{NE}$ on the $\mathrm{Pb}$ concentrations in the shoots of rainbow pink after applying 2 mmol EDTA kg ${ }^{-1}$ soil (Fig. 4). The $\mathrm{Pb}$ concentrations in the shoots after applying 2 mmol EDTA kg ${ }^{-1}$ soil were $121 \pm 17.5 \mathrm{mg} \mathrm{kg}^{-1}$ (Pb-treated soil) and $120 \pm 3.54 \mathrm{mg} \mathrm{kg}^{-1}$ (Cd-Pb-treated soil). The added $\mathrm{Cd}$ in $\mathrm{Pb}$-treated soils had $\mathrm{NE}$ on the $\mathrm{Pb}$ concentration in the shoots after applying 2 mmolEDTA kg ${ }^{-1}$ soil. However, the addition of $\mathrm{Cd}(\mathrm{Cd}-\mathrm{Pb}$-treated soil) had a drastic effect on the $\mathrm{Pb}$ concentrations in the shoots after applying 5 mmol EDTA kg-1 soil. The $\mathrm{Pb}$ concentration significantly decreased from about $314 \pm 40.7 \mathrm{~m} \mathrm{~kg}^{-1}$ in Pb-treated soil to $122 \pm 34.7 \mathrm{mg} \mathrm{kg}^{-1}$ in $\mathrm{Cd}-\mathrm{Pb}$-treated soil after applying $5 \mathrm{mmol} \mathrm{EDTA} \mathrm{kg}^{-1}$ soil $(p<0.05)$. The addition of $\mathrm{Cd}$ in $\mathrm{Pb}$-treated soil had an $\mathrm{IH}$ effect on the $\mathrm{Pb}$ concentration in the shoots with the treatment of 5 mmol EDTA kg-1 soil. After applying 2 mmol EDTA kg-1 soil to the $\mathrm{Zn}-\mathrm{Pb}$-treated soils, the $\mathrm{Pb}$ concentrations in the shoots increased significantly compared to that in the $\mathrm{Pb}$-treated soils $(p<0.05)$ (Fig. 4). The concentrations of $\mathrm{Pb}$ in the shoots increased significantly from $121 \pm 17.5 \mathrm{mg} \mathrm{kg}^{-1}$ (Pb-treated soil) to $269 \pm 39.8 \mathrm{mg} \mathrm{kg}^{-1}$ ( $\mathrm{Zn}-\mathrm{Pb}$-treated soil) after applying 2 mmolEDTA kg ${ }^{-1}$ soil $(p<0.05)$. Zinc had an EH effect on the $\mathrm{Pb}$ concentration in the shoot of plant after applying 2 mmol EDTA kg ${ }^{-1}$ soil, but changed to an IH effect after applying $5 \mathrm{mmol} \mathrm{EDTA} \mathrm{kg}^{-1}$ soil. The Pb concentration in the shoots 
decreased significantly from $314 \pm 40.7$ to $176 \pm 33.5 \mathrm{mg} \mathrm{kg}^{-1}$ after applying $5 \mathrm{mmol} \mathrm{EDTA} \mathrm{kg}^{-1}$ soil $(p<0.05)$.

\section{Discussion}

Table 4 shows the interactions between the metal concentration in the soil and in the shoot of rainbow pink when we consider the change of metal concentrations in the shoot of plant. Result demonstrated that without applying EDTA, the addition of $\mathrm{Zn}$ or $\mathrm{Pb}$ had an $\mathrm{EH}$ effect on the $\mathrm{Cd}$ uptake in plants and $\mathrm{Cd}$ had an $\mathrm{IH}$ effect on the $\mathrm{Zn}$ uptake in plants. The observed result was identical with those obtained in previous studies [16-20,39]. If no EDTA was applied, the uptake of metals in the shoots of rainbow pink was controlled by the characteristic of metals in soil. Among the three metals used in this study, cadmium was rapidly uptake by plants compared to $\mathrm{Pb}$ and $\mathrm{Zn}$ [39]. Rainbow pink accumulated significantly higher $\mathrm{Cd}$ concentration in their shoots when grown in the $\mathrm{Cd}-\mathrm{Zn}$ or $\mathrm{Cd}-\mathrm{Pb}$-treated soil in relative to Cd-treated soil. The existence of $\mathrm{Cd}$, thus, has inhibition effect on the uptake of $\mathrm{Zn}$. Whether the addition with EDTA or not and the concentration of added EDTA affected the interactions between the three metals. After applying two concentrations of EDTA solutions, the $\mathrm{EH}$ effect of adding $\mathrm{Zn}$ on the $\mathrm{Cd}$ concentration in the shoots changed to an IH effect in 2 mmol EDTA kg ${ }^{-1}$ soil and NE in the treatment of 5 mmolEDTA kg-1 soil. The total concentration of artificially spiked $\mathrm{Cd}, \mathrm{Zn}$, and $\mathrm{Pb}$ in this study was about $0.089,1.53$, and $4.82 \mathrm{mmol} \mathrm{kg}^{-1}$, respectively. When we use an assumed chelating ratio (EDTA:metal) of 1:1, application of 2 mmol EDTA $\mathrm{kg}^{-1}$ soil was sufficiently to increase the $\mathrm{Zn}$ concentration in soil solution of $\mathrm{Cd}-\mathrm{Zn}$-treated soil except for $\mathrm{Pb}$. Furthermore, $\mathrm{Zn}$ is also an essential element for the growth of plants. Rainbow pink thus accumulated more $\mathrm{Zn}$ when grown in the $\mathrm{Cd}-\mathrm{Zn}$-treated soil after applying 2 mmolEDTA $\mathrm{kg}^{-1}$ soil. $\mathrm{Zn}$ thus has inhibition effect on the uptake of $\mathrm{Pb}$ in the treatment of 2 mmolEDTA kg-1 soil. In the treatment of 5 mmol EDTA kg ${ }^{-1}$ soil, the added EDTA was sufficiently to form complexes with the whole $\mathrm{Pb}$ in soil because of the higher formation constant of EDTA-Pb complex $\left(\log K_{\mathrm{f}}=19.0\right)$ compared to EDTA-Cd complex $\left(\log K_{\mathrm{f}}=17.4\right)$ and EDTA-Zn complex $\left(\log K_{\mathrm{f}}=17.5\right)$. After applying $5 \mathrm{mmolEDTA} \mathrm{kg}^{-1}$ soil, rainbow pink accumulated more $\mathrm{Pb}$ concentration when grown in the $\mathrm{Pb}$-treated soil in relative to $\mathrm{Cd}-\mathrm{Pb}$ - or $\mathrm{Zn}-\mathrm{Pb}$-treated soil.
The no effect of addition of $\mathrm{Cd}$ or $\mathrm{Zn}$ to soil on the $\mathrm{Pb}$ concentration in the shoots without applying EDTA solutions changed to an IH effect after applying 5 mmol EDTA kg ${ }^{-1}$ soil.

There was a linear relationship between the $\mathrm{Cu}$ and $\mathrm{Zn}$ concentration in soil solution and their uptake of sunflowers in the presence of EDDS [40]. In the absence of chelating agents, experimental result of previous study indicated that there was a logarithmic relationship between the $\mathrm{Cd}$ concentration in the leaf and stem or grain part of wheat and that in soil solution or in soil extracted with $0.05 \mathrm{M}$ EDTA or $0.005 \mathrm{M}$ DTPA [41]. In the end of EDTA-enhanced phytoextraction experiment, there was also a logarithmic relationship between the $\mathrm{Zn}$ or $\mathrm{Pb}$ concentration in the shoot of rainbow pink and that in soil solution [6]. However, the final $\mathrm{Zn}$ and $\mathrm{Pb}$ concentration of shoot was not same as that uptake before the addition of EDTA. During chelant-assisted phytoextraction, plants might have different uptake behaviors (or linear uptake model) in the presence of chelating agents [40].

In this study, we assumed that rainbow pink uptake metals evenly during whole 28 days experiment and their uptake in the last 7 days after applying EDTA was assumed about $25 \%$ of the total uptake. For single or combined metals-contaminated soils, there are logarithmic relationships between the metal concentration in soil solution and that in the shoots of rainbow pink in the presence of 2 or 5 mmol EDTA kg ${ }^{-1}$ soil (Fig. 5). Because of enhancement or inhibition interactions between metals (Table 4$)$, the correlation coefficients $\left(R^{2}\right)$ between metals concentration in the shoot of rainbow pink and that in soil solution in the presence of EDTA are only $0.12(\mathrm{Cd}), 0.33(\mathrm{Zn})$, and $0.42(\mathrm{~Pb})$, respectively (Fig. 5). There are some drawbacks when using above assumption to estimate the uptake of metals by rainbow pink in the presence of EDTA. Because the objective of this study is to assess the interaction between $\mathrm{Cd}, \mathrm{Zn}$, and $\mathrm{Pb}$, it is difficult to assess the uptake behavior because we do not have enough data in the presence of EDTA. The uptake of metals by rainbow pink might not evenly during the whole 28 days and the interactions of metals will also affect the metal concentration in the shoots of plants. For further study to investigate the uptake behavior of metals during chelant-assisted phytoextraction, the experimental design should separate into two parts (i.e. with or without applying chelating agents). The metal uptake of plants in the absence or presence of chelating agents will help us for further understanding the uptake behavior during chelant-assisted phytoextraction.

Table 4

The interactions between the metal in soil and concentration in the shoot of rainbow pink $\left(\mathrm{mg} \mathrm{kg}^{-1}\right)$ when considering the concentration change of metal in the shoot of plant

\begin{tabular}{|c|c|c|c|c|c|c|c|c|c|}
\hline & \multicolumn{9}{|c|}{ EDTA treatments } \\
\hline & \multicolumn{3}{|c|}{ Control $\left(0 \mathrm{mmol}_{\mathrm{EDTA} \mathrm{kg}}{ }^{-1}\right)$} & \multicolumn{3}{|c|}{2 mmol EDTA kg ${ }^{-1}$} & \multicolumn{3}{|c|}{5 mmol EDTA kg ${ }^{-1}$} \\
\hline & $\mathrm{Cd}$ & $\mathrm{Zn}$ & $\mathrm{Pb}$ & $\mathrm{Cd}$ & $\mathrm{Zn}$ & $\mathrm{Pb}$ & $\mathrm{Cd}$ & $\mathrm{Zn}$ & $\mathrm{Pb}$ \\
\hline \multicolumn{10}{|c|}{ Added metal } \\
\hline $\mathrm{Cd}$ & - & $\mathrm{IH}$ & $\mathrm{NE}$ & - & $\mathrm{NE}$ & $\mathrm{NE}$ & - & $\mathrm{NE}$ & $\mathrm{IH}$ \\
\hline $\mathrm{Zn}$ & $\mathrm{EH}$ & - & $\mathrm{NE}$ & $\mathrm{IH}$ & - & $\mathrm{EH}$ & $\mathrm{NE}$ & - & $\mathrm{IH}$ \\
\hline
\end{tabular}

EH, enhancement; IH, inhibition; NE, no effect; -, no effect for the same element. 

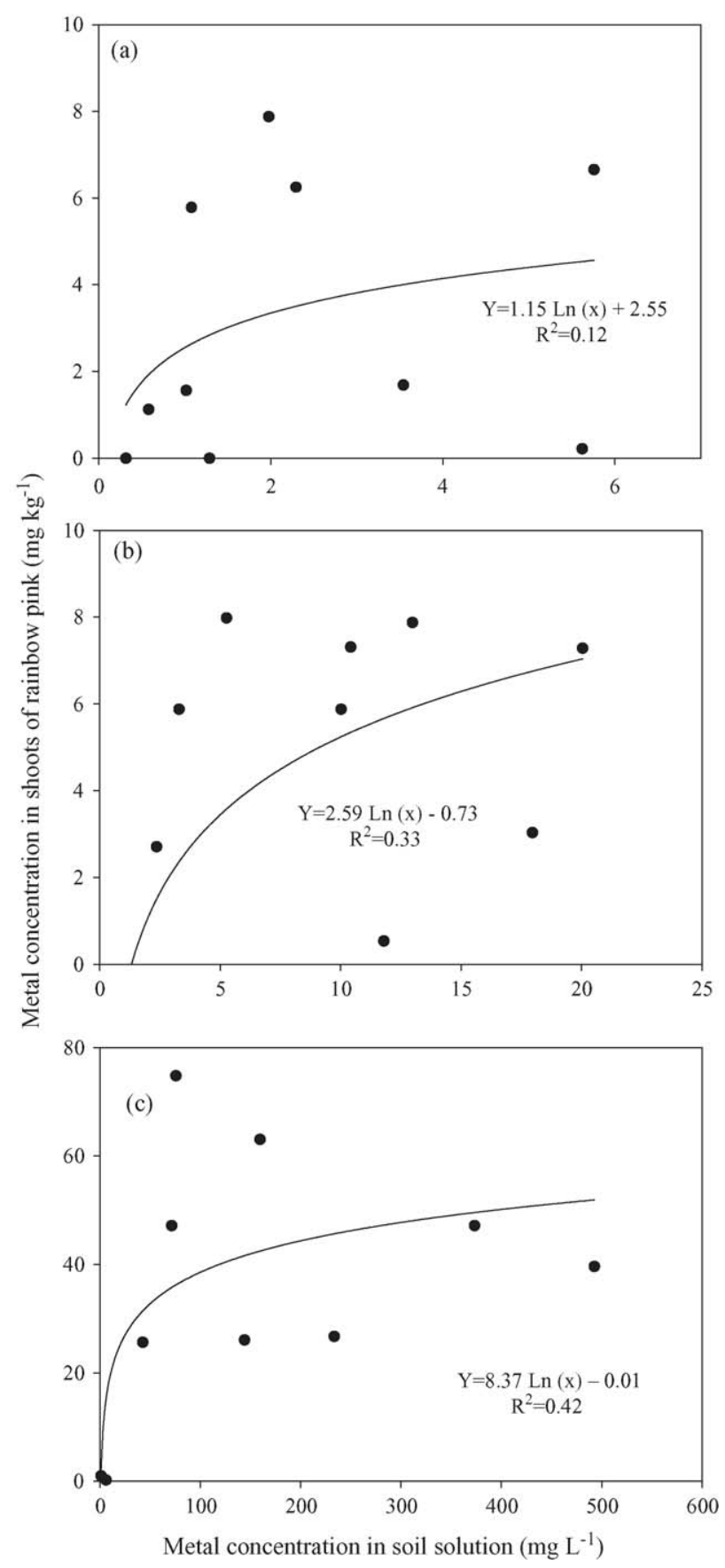

Fig. 5. The relationship between the concentrations of: (a) Cd, (b) Zn, and (c) $\mathrm{Pb}$ in the soil solution and in the shoot of rainbow pink in the presence of EDTA.

\section{Conclusion}

Experimental result of the phytoextraction capacity study showed that rainbow pink has the potential to accumulate high concentrations of metals from metal-contaminated soils after growing for 50 days. In single or combined metalcontaminated soils used in interaction study, the application of 5 mmol EDTA $\mathrm{kg}^{-1}$ soil significantly increased the $\mathrm{Cd}, \mathrm{Zn}$, and $\mathrm{Pb}$ concentrations in the soil solution $(p<0.05)$. The application rate of 2 mmol EDTA kg-1 soil for silty clay soil utilized in this study was too low to increase the concentrations of metals in soil solutions. However, EDTA should be used as a reference compound and is not recommended to be in situ used in the contaminated site because it will resistant to biodegradation.

Without applying EDTA, Pb had an EH effect on the uptake of $\mathrm{Cd}$ in rainbow pink; the EH effect was not affected by the application of 2 mmolEDTA kg ${ }^{-1}$ soil. Cadmium had an IH effect on the uptake of $\mathrm{Zn}$ in rainbow pink in control without applying EDTA, but had NE after applying 2 or 5 mmol EDTA kg ${ }^{-1}$ soil. Because of the greater formation constant of EDTA-Pb complex compared to Cd-EDTA and Zn-EDTA and the sufficient amounts of added EDTA, the existence of $\mathrm{Cd}$ or $\mathrm{Zn}$ at the same time inhibited the uptake of $\mathrm{Pb}$ in rainbow pink after applying 5 mmolEDTA kg-1 soil. The experimental results of this study revealed that some interactions existed in the combined metal-contaminated soils and that the interactions of these metals affected the result of phytoremediation.

\section{Acknowledgment}

The authors would like to thank the National Science Council of Taiwan for financially supporting this research under contract number NSC 91-2621-B-002-003.

\section{References}

[1] P.B.A.N. Kumar, V. Dushenkov, H. Motto, I. Raskin, Phytoextraction: the use of plants to remove heavy metals from soils, Environ. Sci. Technol. 29 (1995) 1232-1238.

[2] R.L. Chaney, M. Malik, Y.M. Li, S.L. Brown, E.P. Brewer, J.S. Angle, A.J.M. Baker, Phytoremediation of soil metals, Environ. Biotechnol. 8 (1997) 279-284.

[3] E. Lombi, W.W. Wenzel, D.C. Adriano, Soil contamination, risk reduction and remediation, Land Contam. Reclam. 6 (1998) 183-197.

[4] W.W. Wenzel, E. Lombi, D.C. Adriano, Biogeochemical processes in the rhizosphere: role in phytoremediation of metal-polluted soils, in: M.N.V. Prasad, J. Hagemeyer (Eds.), Heavy Metal Stress in Plants, Springer, New York, USA, 1999, pp. 273-303.

[5] M.M. Lasat, Phytoextraction: a review of biological mechanisms, J. Environ. Qual. 31 (2002) 109-120.

[6] H.Y. Lai, Z.S. Chen, Effects of EDTA on solubility of cadmium, zinc, and lead and their uptake by rainbow pink and vetiver grass, Chemosphere 55 (2004) 421-430.

[7] A.J.M. Baker, S.P. McGrath, R.D. Reeves, J.A.C. Smith, Metal hyperaccumulator plants: a review of the ecology and physiology of a biological resource for phytoremediation of metal-polluted soils, in: N. Terry, G. Bañuelos (Eds.), Phytoremediation of Contaminated Soil and Water, CRC Press LLC, USA, 2000, pp. 85-107.

[8] M.J. Blaylock, D.E. Salt, S. Dushenkov, O. Zakharova, C. Gussman, Y. Kapulnik, B.D. Ensley, I. Raskin, Enhanced accumulation of $\mathrm{Pb}$ in Indian mustard by soil-applied chelating agents, Environ. Sci. Technol. 31 (1997) $860-865$.

[9] J.W. Huang, J. Chen, W.R. Berti, S.D. Cunningham, Phytoremediation of lead-contaminated soils: role of synthetic chelates in lead phytoextraction, Environ. Sci. Technol. 31 (1997) 800-805.

[10] J. Wu, F.C. Hsu, S.D. Cunningham, Chelate-assisted $\mathrm{Pb}$ phytoremediation: $\mathrm{Pb}$ availability, uptake, and translocation constraints, Environ. Sci. Technol. 33 (1999) 1898-1904.

[11] E. Lombi, F.J. Zhao, S.J. Dunham, S.P. McGrath, Phytoremediation of heavy metal-contaminated soils: natural hyperaccumulation versus chemically enhanced phytoextraction, J. Environ. Qual. 30 (2001) 1919-1926.

[12] S. Tandy, R. Schulin, B. Nowack, The influence of EDDS on the uptake of heavy metals in hydroponically grown sunflowers, Chemosphere 62 (2006) 1454-1463. 
[13] H.Y. Lai, Z.S. Chen, The EDTA effect on phytoextraction of single and combined metals-contaminated soils using rainbow pink (Dianthus chinensis), Chemosphere 60 (2005) 1062-1071.

[14] H. Chen, T. Cutright, EDTA and HEDTA effects on Cd, Cr, and Ni uptake by Helianthus annuus, Chemosphere 45 (2001) 21-28.

[15] I.M. McKenna, R.L. Chaney, F.M. Williams, The effects of cadmium and zinc interactions on the accumulation and tissue distribution of zinc and cadmium in lettuce and spinach, Environ. Pollut. 79 (1993) 113-120.

[16] D.C. Adriano, Trace Elements in the Terrestrial Environment, Spring-Verlag New York Inc., USA, 1986.

[17] R.W. Carlson, G.L. Rolfe, Growth of rye grass and fescue as affected by lead-cadmium-fertilizer interaction, J. Environ. Qual. 8 (1979) 348-352.

[18] J.J. Hassett, J.E. Miller, D.E. Koeppe, Interaction of lead and cadmium on maize root growth and uptake of lead and cadmium by roots, Environ. Pollut. 11 (1976) 297-302.

[19] R.W. Carlson, F.A. Bazzaz, Growth reduction in americam sycamore (Plantanus Occidentalis L.) caused by $\mathrm{Pb}-\mathrm{Cd}$ interaction, Environ. Pollut. 12 (1977) 243-253.

[20] A. Kabata-Pendias, H. Pendias, Trace Elements in Soils and Plants, CRC Press LLC, Boca Raton, Florida, USA, 2001.

[21] Z.S. Chen, D.Y. Lee, Evaluation of remediation techniques on two cadmium-polluted soils in Taiwan, in: I.K. Iskandar, D.C. Adriano (Eds.), Remediation of Soils Contaminated with Metals, Science Reviews, Northwood, UK, 1997, pp. 209-223.

[22] E.O. McLean, Soil pH and lime requirement, in: A.L. Page, et al. (Eds.), Methods of Soil Analysis. Part 2. Chemical and Microbiological Properties, Agronomy Monograph 9, second ed., Madison, WI, USA, 1982, pp. 199-224.

[23] G.W. Gee, J.W. Bauder, Particle-size analysis, in: A. Klute, et al. (Eds.), Methods of Soil Analysis. Part 1. Physical and Mineralogical Method, Agronomy Monograph 9, second ed., Madison, WI, USA, 1986, pp. 383-412.

[24] D.W. Nelson, L.E. Sommers, Total carbon, organic carbon and organic matter, in: A.L. Page, et al. (Eds.), Methods of Soil Analysis. Part 2. Chemical and Microbiological Properties, Agronomy Monograph 9, second ed., Madison, WI, USA, 1982, pp. 539-580.

[25] G.W. Thomas, Exchangeable cations, in: A.L. Page, et al. (Eds.), Methods of Soil Analysis. Part 2. Chemical and Microbiological Properties, Agronomy Monograph 9, second ed., Madison, WI, USA, 1982, pp. 159-166.

[26] J.K. Rhoades, Cation exchange capacity, in: A.L. Page, et al. (Eds.), Methods of Soil Analysis. Part 2. Chemical and Microbiological Properties, Agronomy Monograph 9, second ed., Madison, WI, USA, 1982, pp. 149-158.

[27] EPA/ROC, The digestion methods of heavy metal in soils by aqua regia, Method code no: NIEA S321.62C, Environmental Protection Administration of Taiwan ROC, Taipei, Taiwan, 2002.
[28] M.E. Harmon, K. Lajtha, Analysis of detritus and organic horizons for mineral and organic constitutes, in: G.P. Robertson, D.C. Coleman, C.S. Bledsoe, P. Sollins (Eds.), Standard Soil Methods for Long-Term Ecological Research, Oxford University Press, Inc., New York, USA, 1999, pp. 143-165.

[29] M.J. Mench, V.L. Didier, M. Loffler, A. Gomez, P. Masson, A mimicked in situ remediation study of metal-contaminated soils with emphasis on cadmium and lead, J. Environ. Qual. 23 (1994) 58-63.

[30] W.L. Lindsay, W.A. Norvell, Development of a DTPA soil test for zinc, iron, manganese, and copper, Soil Sci. Soc. Am. J. 42 (1978) 421-428.

[31] R.C. Stover, L.E. Sommers, D.J. Silviera, Evaluation of metals in wastewater sludge, J. Water Pollut. Control Fed. 48 (1976) 2165-2175.

[32] G. Sposito, L.J. Lund, A.C. Chang, Trace metal chemistry in arid-zone field soils amended with sewage sludge: Fractionation of $\mathrm{Ni}, \mathrm{Cu}, \mathrm{Zn}$, $\mathrm{Cd}$, and $\mathrm{Pb}$ in solid phases, Soil Sci. Soc. Am. J. 46 (1982) 260264.

[33] S.P. Mathur, M.P. Levesque, The effects of using copper for mitigating histosol subsidence on: 2 . The distribution of copper, manganese, zinc, and iron in an organic soil, mineral sublayers, and their mixtures in the context of setting a threshold of phytotoxic soil-copper, Oil Sci. 135 (1983) 166-176.

[34] K.C. Jones, P.J. Peterson, B.E. Davies, Extraction of silver from soils and its determination by atomic absorption spectrometry, Geoderma 33 (1984) $157-168$.

[35] S.P. Goldberg, K.A. Smith, Soil manganese: $E$ values, distribution of manganese-54 among soil fractions, and effects of drying, Soil Sci. Soc. Am. J. 48 (1984) 559-564.

[36] Y.M. Luo, L.H. Wu, X.J. Jiang, S.C. Wu, P. Christie, Chelate-enhanced phytoextraction of metal-contaminated soils and its environmental risk, in: Y.M. Luo, S.P. McGrath, Z.H. Cao, F.J. Zhao, Y.X. Chen, J.M. Xu (Eds.), Proceeding of the 2000 International Conference of Soil Remediation, Hangzhou, China, October 15-19, 2000, pp. 161-165.

[37] M. Puschenreiter, G. Stöger, E. Lombi, O. Horak, W.W. Wenzel, Phytoextraction of heavy metal contaminated soils with Thlaspi goesingense and Amaranthus hybridus: rhizosphere manipulation using EDTA and ammonium sulfate, J. Plant Nutr. Soil Sci. 164 (2001) 615-621.

[38] D. Hammer, C. Keller, Changes in the rhizosphere of metal-accumulating plants evidenced by chemical extractants, J. Environ. Qual. 31 (2002) 1561-1569.

[39] B.J. Alloway, Heavy Metals in Soils, Blackie Academic \& Professional, Glasgow, UK, 1995.

[40] S. Tandy, R. Schulin, B. Nowack, Uptake of metals during chelant-assisted phytoextraction with EDDS related to the solubilized metal concentration, Environ. Sci. Technol. 40 (2006) 2753-2758.

[41] T.M. Lee, H.Y. Lai, Z.S. Chen, Effect of chemical amendments on the concentration of cadmium and lead in long-term contaminated soils, Chemosphere 57 (2004) 1459-1471. 